\title{
Editorial
}

\section{Clean Air Journal: supporting discussion on key African air quality issues}

\author{
Editors in Chief \\ Rebecca M Garland ${ }^{1}{ }^{1}$, Gregor T Feig ${ }^{(12}$, Kristy Langerman ${ }^{3}{ }^{3}$ \\ ${ }^{1}$ Climate and Air Quality Modelling Research Group, CSIR, Pretoria, South Africa \\ ${ }^{2}$ South African Environmental Observation Network, South Africa \\ ${ }^{3}$ Department of Geography, Environmental Management and Energy Studies, University of Johannesburg, Johannesburg, South Africa
}

https://doi.org/10.17159/caj/2020/30/1.8520

The face of the Clean Air Journal changed in October 2019 with the launch of a new website and submission systems that has moved us online. Previously, each article had long email trails associated with its journey from submission to publication; this new online system has greatly assisted the Editorial Team with streamlining this process. We know there have been some teething problems with the new website, and we thank all Clean Air Journal authors, reviewers, and readers for their patience as we make this exciting change. This website has been developed as part of the Academy of Science of South Africa's (ASSAf) Khulisa Journals platform (https://journals.assaf.org.za/ index). The Clean Air Journal joins seven other top South African journals in the Khulisa Journals platform that aims to support open-access South African journals.

In this issue, in addition to the regular front section that provides viewpoints and highlights on the latest happenings in African air quality, there is a featured section on air quality challenges in low-income settlements. The compilation of the contributions from researchers working in Africa on this issue aims to support the discussion in the community to share challenges, successes, and lessons learned on addressing this complex issue.

Additionally, the front material includes a call for papers for the first ever special issue of Clean Air Journal. This special issue of the Clean Air Journal will be a synthesis of atmospheric research conducted on the Highveld since 2004, and will provide an update of Tyson, Kruger and Louw (1988). It is intended to be a resource for policymakers, managers, students, and scientists.

The Clean Air Journal is committed to supporting the African air quality research community through highlighting and supporting discussion on key topics, publishing high-quality research articles, and by providing all our material open-access.

\section{References}

Tyson, P.D., Kruger, F.J. and Louw, C.W. (eds), 1988: Atmospheric Pollution and its Implications in the Eastern Transvaal Highveld, South African National Scientific Programmes Report No. 150, Council for Scientific and Industrial Research, Pretoria 